\title{
Analisis Pendapatan Asli Daerah Sektor Perusahaan Daerah di Kabupaten Lamongan
}

\author{
Abid Muhtarom \\ Universitas Islam Lamongan \\ Email: abid@unisla.ac.id/ abid@chelseafc.or.id
}

\begin{abstract}
Regional Income is income earned something of a region directly. The greater the income the greater the area of regional development can be implemented in accordance with the regional budget. In order to compile this study, the authors conducted a descriptive research with a qualitative approach. Namely to describe the phenomenon that is qualitatively with expectations could potentially openinterpretation of subjective interpretation. By interpreting the data on the reception pattern profit company owned by the regional implications to increase revenue in the budget Lamongan District Government. This research was conducted in the district of Lamongan in January to June 2015. Based on the results of the analysis of the calculation of the contribution that profit enterprises in the year 2010 to the year 2014 still has contribution but not optimal. This means that the profit enterprises still contribute to regional revenue Lamongan though not completely.
\end{abstract}

Keywords: Regional Income, Local Company, Regionally-Owned Enterprises

\section{PENDAHULUAN}

Pendapatan Asli Daerah (PAD) merupakan sesuatu pendapatan yang diperoleh dari daerah secara langsung. Semakin besar pendapatan asli daerah tersebut semakin besar pula pembangunan daerah dapat di laksanakan sesuai dengan APBD daerah. Sesuai dengan data yang diperoleh dari BPS dapat disimpulkan sebagai berikut: Tingkat pertumbuhan ekonomi suatu daerah sangat di tentukan oleh faktor lokal dan eksternal. Faktor lokal meliputi: ketersediaan sumber daya alam, kualitas sumber daya manusia, kemampuan teknologi, permodalan dan kewirausahaan. Sedangkan faktor eksternal diantaranya ialah perkembangan situasi perekonomian nasional maupun internasional serta berbagai kebijakan pemerintah baik yang berkaitan dengan sektor riil maupun moneter. Selama tahun 2011 kondisi perekonomian nasional cukup stabil, kurs rupiah dan suku bunga bank cenderung menurun. Hal ini sangat menguntungkan bagi perkembangan perekonomian Kabupaten Lamongan yakni ditandai dengan semakin meningkatnya nilai investasi dan tingkat pertumbuhan ekonominya yang cukup dinamis. Besarnya pertumbuhan ekonomi suatu daerah, tercermin dari pertumbuhan PDRB atas dasar harga konstannya. Dari hasil penghitungan PDRB tahun 2011 pertumbuhan ekonomi sebesar $7,02 \%$.

Pertumbuhan ini mengalami percepatan bila dibanding tahun 2010 yang tumbuh 6,98\%. Pertumbuhan positif serta percepatan ini berlanjut pada tahun 2012 dibandingkan tahun 2011. Dengan PDRB atas dasar harga konstan Rp.7.098.168.752.000 membentuk pertumbuhan pada tahun 2012 sebesar 7,13\%, besaran pertumbuhan pada tahun ini menjadi pertumbuhan terbesar dalam satu 
dekade tertentu. Di tahun 2013 pertumbuhan positif terus berlanjut meskipun tidak mengalami percepatan sebagaimana tahun-tahun sebelumnya atau dengan kata lain pertumbuhan tahun ini mengalami perlambatan dibanding tahun 2012. (BPS Kabupaten Lamongan).

Dalam rangka mengoptimalkan pemanfaatan sumber-sumber penerimaan untuk peningkatan pendapatan daerah, maka kiranya perlu dianalisis potensi ekonomi (kontribusi) dari masing-masing sektor. Sehingga pada akhirnya dapat menyusun perencanaan pembangunan di daerah secara efektif dan efisien sebagai modal pembangunan dalam mewujudkan otonomi daerah. Dari pernyataan tersebut maka dapat disimpulkan bahwa keberhasilan otonmi daerah tidak terlepas dari kmampan suatu daerah dalam bidang keuangan. Keuangan daerah sangat penting sebagai aspek pembangunan daerah, dalam hal ini dimana cara daerah tersebut dapat menciptakan sumber pendapatan dan penerimaan daerah sendiri tanpa tergantung dari Pemerintah pusat yang akan berpengaruh terhadap kinerja keuangan, peningkatan kesejahteaan masyarakat serta pemberian pelayanan publik apakah berjalan secara efektif dan efisien atau tidak.

Hasil perusahaan milik daerah dan hasil pengelolaan kekayaan daerah yang dipisahkan. Hasil perusahaan milik daerah merupakan pendapatan daerah dari keuntungan bersih perusahaan daerah yang berupa dana pembangunan daerah dan bagian untuk anggaran belanja daerah yang disetor ke kas daerah, baik perusahaan daerah yang dipisahkan, sesuai dengan motif pendirian dan pengelolaan, maka sifat perusahaan dareah adalah suatu kesatuan produksi yang bersifat menambah pendapatan daerah, memberi jasa, dan memperkembangkan perekonomian daerah Lamongan. Lebih lanjut penelitian ini ingin mengetahui seberapa besar peranan kontribusi hasil perusahaan milik daerah (Pendapatan Perusahaan Daerah) dalam peningkatan Pendapatan Asli Daerah (PAD) kabupaten Lamongan.

\section{KAJIAN PUSTAKA \\ Pendapatan Asli Daerah}

Pendapatan Asli Daerah (PAD) adalah salah satu sumber penerimaan daerah yang mendukung kemampuan keuangan daerah. Pengertian Pendapatan Asli Daerah menurut Undang-Undang No.28 Tahun 2009 yaitu sumber keuangan daerah yang digali dari wilayah daerah yang bersangkutan yang terdiri dari hasil pajak daerah, hasil retribusi daerah, hasil pengelolaan kekayaan daerah yang dipisahkan dan lain-lain pendapatan asli daerah yang sah.

Menurut Nurcholis (2007: 182) pendapatan asli daerah adalah pendapatan yang diperoleh daerah dari penerimaan pajak daerah, retribusi daerah, laba perusahaan daerah dan lain-lain yang sah. Pendapatan Daerah adalah semua hak daerah yang diakui sebagai penambah nilai kekayaan bersih dalam periode anggaran tertentu (UU No. 32 Tahun 2004 tentang pemerintahan daerah), pendapatan daerah berasal dari dana perimbangan pusat dan daerah juga berasal dari daerah itu sendiri yakni pendapatan asli daerah serta lain-lain pendapatan yang sah.

Pendapatan Asli Daerah adalah penerimaan yang diperoleh dari sumbersumber dalam wilayahnya sendiri yang dipungut berdasarkan peraturan daerah yang sesuai dengan peraturan perundang-undangan yang berlaku yang terdiri atas: 
a. Hasil pajak daerah yaitu pungutan yang dilakukan oleh pemerintah daerah kepada semua objek pajak, seperti orang/ badan, benda bergerak/ tidak bergerak.

b. Hasil retribusi daerah, yaitu pungutan yang dilakukan sehubungan dengan suatu jasa/fasilitas yang berlaku oleh pemerintah daerah secara langsung dan nyata.

c. Hasil perusahaan milik daerah dan hasil pengelolaan kekayaan daerah yang dipisahkan antara lain laba dividen, penjualan saham milik daerah.

d. Lain-lain pendapatan asli daerah yang sah antara lain hasil penjualan aset tetap dan jasa giro.

Pendapatan Asli Daerah (PAD) yang tinggi belum merupakan jaminan tingginya pendapatan masyarakat di suatu daerah (regional income). Namun demikian, tingginya PAD dapat menjadi sumberdaya yang sangat penting bagi pemerintah daerah di dalam pengembangan wilayah termasuk dalam peningkatan pendapatan masyarakatnya (Rustiadi, Ghifari, Suradinata, Wijanarko, Supranto, Karmaji, Oyong, Nurbaya dan Martha, 2010). Perolehan PAD diperlukan manajemen pemanfaatan dana yang mampu digunakan semaksimal mungkin bagi kemakmuran masyarakat yang sebesar-besarnya melalui program-program dan kegiatan-kegiatan yang diluncurkan pemerintah daerah tersebut (Susanto, Ghifari, Suradinata, Wijanarko, Supranto, Karmaji, Oyong, Nurbaya dan Martha, 2010). Adapun sumber-sumber pendapatan asli daerah menurut Undang-Undang RI No. 32 Tahun 2004 terdiri dari:

a. Hasil pajak daerah yaitu pungutan daerah menurut peraturan yang ditetapkan oleh daerah untuk pembiayaan rumah tangganya sebagai badan hukum publik. Pajak daerah sebagai pungutan yang dilakukan pemerintah daerah yang hasilnya digunakan untuk pengeluaran umum yang balas jasanya tidak langsung diberikan sedang pelaksanaanya bisa langsung dipaksakan.

b. Hasil retribusi daerah yaitu pungutan yang telah secara sah menjadi pungutan daerah sebagai pembayaran pemakaian atau karena memperoleh jasa pekerjaan, usaha atau milik pemerintah daerah yang bersangkutan. Retribusi daerah mempuyai sifat-sifat yaitu pelaksanaanya besrifat ekonomis, ada imbalan langsung walau harus memenuhi persyaratanpersyaratan formil maupun materiil, tetapi ada alternatif untuk mau tidak membayar, merupakan pungutan yang sifatnya budgetatifnya tidak menonjol, dalam hal-hal tertentu retribusi daerah adalah pengembalian biaya yang telah dilakukan oleh pemerintah daerah untuk memenuhi permintaan anggota masyarakat.

c. Hasil perusahaan milik daerah dan hasil pengelolaan kekayaan daerah yang dipisahkan. Hasil perusahaan milik daerah merupakan pendapatan daerah dari keuntungan bersih perusahaan daerah yang berupa dana pembangunan daerah dan bagian untuk anggaran belanja daerah yang disetor ke kas daerah, baik perusahaan derah yang dipisahkan, sesuai dengan motif pendirian dan pengelolaan maka sifat perubahan daerah adalah suatu kesatuan produksi yang bersifat menambah pendapatan daerah, memberi jasa, menyelenggarakan kemanfaatan umum dan memperkembengkan perekonomian daerah. 
d. Lain-lain pendapatan yang sah ialah pendapatan-pendapatan yang tidak termasuk dalam jenis-jenis pajak daerah, restibusi daerah, pendapatan dinasdinas. Lain-lain usaha daerah yang sah mempunyai sifat pembuka bagi pemerintah daerah untuk melakukan kegiatan yang menghasilkan baik berupa materi dalam kegiatan tersebut bertujuan untuk menunjang, melapangkan, dan memantapkan suatu kebijakan daerah disuatu bidang tertentu. Dana perimbangan diperoleh melalui bagian pendapatan daerah dari penerimaan pajak bumi dan bangunan dari pedesaan, perkotaan, pertambangan sumber daya alam, dan serta bea perolehan hak atas tanah dan bangunan. Dana perimbangan terdiri atas dana bagi hasil, dana alokasi umum, dan dana alokasi khusus. Lain - lain pendapatan daerah yang sah adalah pendapatan derah dari sumber lain misalnya sumbangan pihak ketiga kepada daerah yang dilaksanakan sesuai dengan peraturan perundangundangan yang berlaku.

Menurut Halim (2013:101) Pendapatan Asli Daerah (PAD) merupakan semua penerimaan daerah yang berasal dari sumber ekonomi asli daerah. Kelompok pendapatan Asli Daerah dipisahkan menjadi 4 jenis pendapatan, yaitu sebagai berikut:
a. Pajak Daerah
b. Retribusi Daerah
c. Hasil Pengelolaan kekayaan milik daerah yang dipisahkan
d. Lain-lain PAD yang sah.

\section{Perusahaan Daerah}

Undang-Undang No.5 Tahun 1962 tentang Perusahaan Daerah memberikan pengertian tentang yang dimaksud dengan Perusahaan Daerah adalah semua perusahaan yang didirikan berdasarkan undang-undang ini yang seluruh atau sebagian modalnya merupakan kekayaan daerah yang dipisahkan, kecuali jika ditentukan lain dengan atau berdasarkan undang-undang.

Sedangkan menurut Undang-Undang RI Nomor 17 Tahun 2003 tentang Keuangan Negara yang dimaksud dengan Perusahaan Daerah adalah badan usaha yang seluruh atau sebagian modalnya diimiliki oleh Pemerintah Daerah. Menurut Elita Dewi (2002:4) mengenai perusahaan daerah adalah sebagai berikut:

a. Perusahaan Daerah adalah kesatuan produksi yang bersifat: Memberi jasa, Menyelenggarakan pemanfaatan umum, Memupuk pendapatan

b. Tujuan perusahaan daerah untuk turut serta melaksanakan pembangunan daerah khususnya dan pembangunan kebutuhan rakyat dengan menggutamakan industrialisasi dan ketentraman serta ketenangan kerja menuju masyarakat yang adil dan makmur.

c. Perusahaan daerah bergerak dalam lapangan yang sesuai dengan urusan rumah tangganya menurut perundang-undangan yang mengatur pokokpokok pemerintahan daerah.

d. Cabang-cabang produksi yang penting bagi daerah dan mengusai hajat hidup orang banyak di daerah, yang modal untuk seluruhnya merupakan kekayaan daerah yang dipisahkan

Selanjutnya Perusahaan Daerah adalah suatu kesatuan produksi yang bersifat memberi jasa, menyelenggarakan kemanfaatan umum dan memupuk pendapatan. Perusahaan Daerah dipimpin oleh suatu Direksi yang jumlah anggota 
dan susunannya ditetapkan dalam peraturan pendiriannya. Direksi berada dibawah pengawasan Kepala Daerah/pemegang saham/saham prioritet atau badan yang ditunjuknya.

Ini berarti bahwa masih ada kemungkinan mengikutsertakan swasta ke dalam perusahaan, dan ini sesuai pula dengan dasar-dasar pemikiran bahwa segala modal yang ada dalam masyarakat yang merupakan pengerahan potensi dana dan tenaga (funds and forces) dapat diikutsertakan.

Sedangkan berdasarkan Keputusan Menteri Dalam negeri dan Otoda Nomor 43 Tahun 2000 tentang Pedoman Kerjasama Perusahaan Daerah dengan Pihak Ketiga Pasal 1, menetapkan bahwa: "Perusahaan daerah adalah semua badan usaha yang modalnya merupakan kekayaan daerah yang dipisahkan dan pendiriannya diprakarsai oleh daerah".

\section{METODE PENELITIAN}

Penelitian Kualitatif ini bersifat deskriptif analitis. Penelitian ini dilaksanakan di wilayah kabupaten Lamongan pada bulan Januari sampai Juni 2015. Untuk menyusun penelitian ini, penulis melakukan penelitian yang bersifat deskriptif dengan pendekatan kualitatif. Yaitu untuk mendeskripsikan fenomena yang secara kualitatif dengan harapan dapat membuka potensi interprestasiinterprestasi subyektif. Dengan menafsirkan data mengenai pola penerimaan Laba Perusahaan milik daerah yang berimplikasi pada peningkatan PAD dalam APBD Pemerintah Kabupaten Lamongan.

\section{PEMBAHASAN}

\section{Kontribusi Laba Perusahaan Daerah (BUMD) Terhadap Pendapatan Asli} Daerah (PAD) Kabupaten Lamongan.

Setelah diketahui total Laba BUMD selama tahun 2010 - 2014, maka dapat dihitung kontribusi Laba BUMD dari tabel diatas bisa diketahui terjadi penurunan Laba BUMD di tahun 2013 dan meningkat kembali di tahun 2014. Pada analisis penelitian ini kontribusi didapat dari perbandingan total Laba BUMD dengan Pendapatan Asli Daerah (PAD). Berikut ini tabel kontribusi Laba BUMD terhadap Pendapatan Asli Daerah (PAD) Kabupaten Lamongan.

\section{PD. Bank Daerah Lamongan}

Tabel 1. Hasil kontribusi Laba PD.BDL tahun 2010 - 2014

\begin{tabular}{ccccl}
\hline Tahun & $\begin{array}{c}\text { Laba } \\
(\mathbf{2})\end{array}$ & $\begin{array}{c}\text { Total Laba } \\
\text { Penyertaan Modal } \\
\text { BUMD } \\
\mathbf{( 3 )}\end{array}$ & $\begin{array}{c}\mathbf{\%} \\
(\mathbf{2} / \mathbf{3})\end{array}$ & Kriteria \\
\hline $\mathbf{2 0 1 0}$ & $1.268 .787 .157,88$ & $1.423 .787 .157,88$ & 89,11 & Sangat berkontribusi \\
\hline $\mathbf{2 0 1 1}$ & $957.699 .976,00$ & $13.248 .936 .779,00$ & 7,23 & Sangat berkontribusi \\
\hline $\mathbf{2 0 1 2}$ & $1.022 .293 .545,00$ & $16.040 .602 .352,00$ & 6,37 & Sangat berkontribusi \\
\hline $\mathbf{2 0 1 3}$ & $1.140 .583 .177,00$ & $15.389 .749 .772,00$ & 7,41 & Sangat berkontribusi \\
\hline $\mathbf{2 0 1 4}$ & $1.678 .304 .715,00$ & $16.091 .497 .784,00$ & 10,42 & Sangat berkontribusi \\
\hline
\end{tabular}




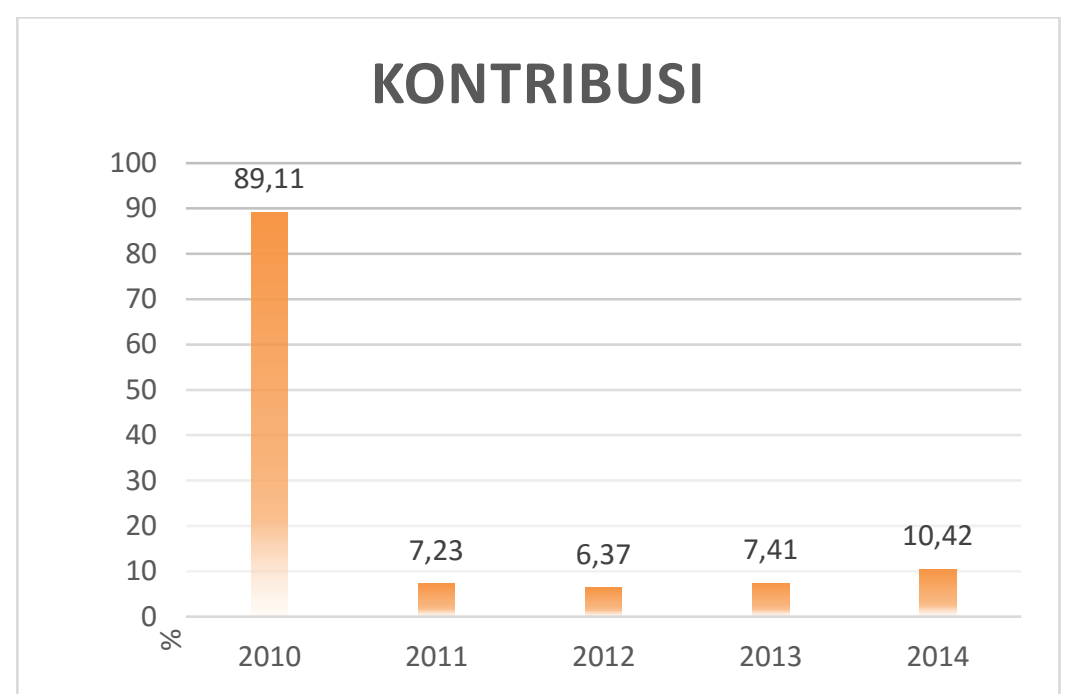

Grafik Hasil kontribusi Laba PD.BDL tahun 2010 - 2014. Dari peritungan tabel diatas dapat diketahui:

a. Pada tahun 2010 didapat kontribusi senilai $89.11 \%$ dengan laba senilai 1.268.787.157,88,00 dibagi dengan total laba penyertaan modal pada PAD senilai 1.423.787.157,88, masuk dalam kategori sangat berkontribusi

b. Pada tahun 2011 didapat kontribusi senilai 7,23\% dengan laba senilai 957.699.976,00 dibagi dengan total laba penyertaan modal pada PAD senilai 13.248.936.779,00, masuk dalam kategori sangat berkontribusi

c. Pada tahun 2012 didapat kontribusi senilai 6,37\% dengan laba senilai 1.022.293.545,00 dibagi dengan total laba penyertaan modal pada PAD senilai 16.040.602.352,00, masuk dalam kategori sangat berkontribusi.

d. Mengalami peningkatan di tahun 2013 dengan kontribusi senilai 7,41\% dengan laba senilai 1.140.583.177,00 dibagi dengan total laba penyertaan modal pada PAD senilai 15.389.749.772,00, masuk dalam kategori sangat berkontribusi.

e. Terjadi peningkatan kembali yang besar ditahun 2014 dengan kontribusi senilai 10,42\% dengan laba senilai 1.678.304.715,00 dibagi dengan total laba penyertaan modal pada PAD senilai 16.091.497.784,00, masuk dalam kategori sangat berkontribusi.

\section{PDAM Kab. Lamongan}

Untuk Perusahaan Daerah Air Minum Kabupaten Lamongan, untuk tahun 2010-2014, belum memberikan kontribusi pada Pendapatan Asli Daerah Kabupaten Lamongan, sebab untuk 5 tahun terakhir kondisi Kinerja PDAM Kabupaten Lamongan mengalami Kerugian, sebab laba yang diperoleh tidak mampu menutupi beban operasional pada PDAM Kabupaten Lamongan hal ini dapat ditunjukkan pada tabel berikut:

Tabel 2. Perbandingan Rasio Aset Perusahaan Dengan Kewajiban

\begin{tabular}{ccccccc}
\hline \multirow{2}{*}{ No } & Uraian & \multicolumn{5}{c}{ Tahun } \\
\cline { 3 - 7 } & & $\mathbf{2 0 1 0}$ & $\mathbf{2 0 1 1}$ & $\mathbf{2 0 1 2}$ & $\mathbf{2 0 1 3}$ & $\mathbf{2 0 1 4}$ \\
\hline \multirow{2}{*}{ T } & Total Asset & 25.947 .121$. & 24.065 .0 & 24.286 .197 & 49.390 .301 & 37.850 .177 .132 \\
& & 153 & 04.575 & .555 & .345 & \\
\hline \multirow{2}{*}{$\mathbf{n n y y y y}$} & Total & 29.919 .773$. & 30.383 .5 & 27.990 .789 & 29.154 .993 & 28.930 .833 .611 \\
& Kewajiban & 615 & 25.252 & .865 & .564 & \\
\hline \multirow{2}{*}{ Jumlah } & $(3,972,652,4$ & $(6,318,52$ & $(3,704,592$, & $20,235,307$ & $8,919,343,521$ \\
& & $62)$ & $0,677)$ & $310)$ &, 781 & \\
\hline
\end{tabular}


Pada kondisi pertumbuhan kinerja keuangan diatas bisa dilihat bahwa perbandingan rasio antara asset perusahaan dengan kewajiban dari tahun 2010 sampai dengan tahun 2014 memperlihatkan bahwa asset perusahaan yang dimiliki $<$ kewajiban yang harus dibayar. Artinya pendapatan atau asset yang dimiliki tidak bisa menutupi kewajiban yang dibayar. Karena lebih besar kewajibannya dari pada assetnya.

\section{PD. Pasar Kabupaten Lamongan}

Tabel 3. Hasil kontribusi Laba PD.PASAR Tahun 2010 - 2014

\begin{tabular}{ccccc}
\hline Tahun & $\begin{array}{c}\text { Laba } \\
(\mathbf{2})\end{array}$ & $\begin{array}{c}\text { Total Laba Penyertaan } \\
\text { Modal BUMD } \\
\mathbf{( 3 )}\end{array}$ & $\begin{array}{c}\mathbf{\%} \\
\mathbf{( 2 / 3 )}\end{array}$ & Kriteria \\
\hline $\mathbf{2 0 1 0}$ & 0 & $1.423 .787 .157,88$ & $0 \%$ & Relatif tidak berkontribusi \\
\hline $\mathbf{2 0 1 1}$ & $207.699 .303,00$ & $13.248 .936 .779,00$ & 1,57 & Kurang berkontribusi \\
\hline $\mathbf{2 0 1 2}$ & $487.308 .807,00$ & $16.040 .602 .352,00$ & 3.03 & Mempuyai kontribusi \\
\hline $\mathbf{2 0 1 3}$ & $149.591 .500,00$ & $15.389 .749 .772,00$ & 0,97 & Relatif tidak berkontribusi \\
\hline $\mathbf{2 0 1 4}$ & $283.193 .096,00$ & $16.091 .497 .784,00$ & 1,75 & Kurang berkontribusi \\
\hline
\end{tabular}

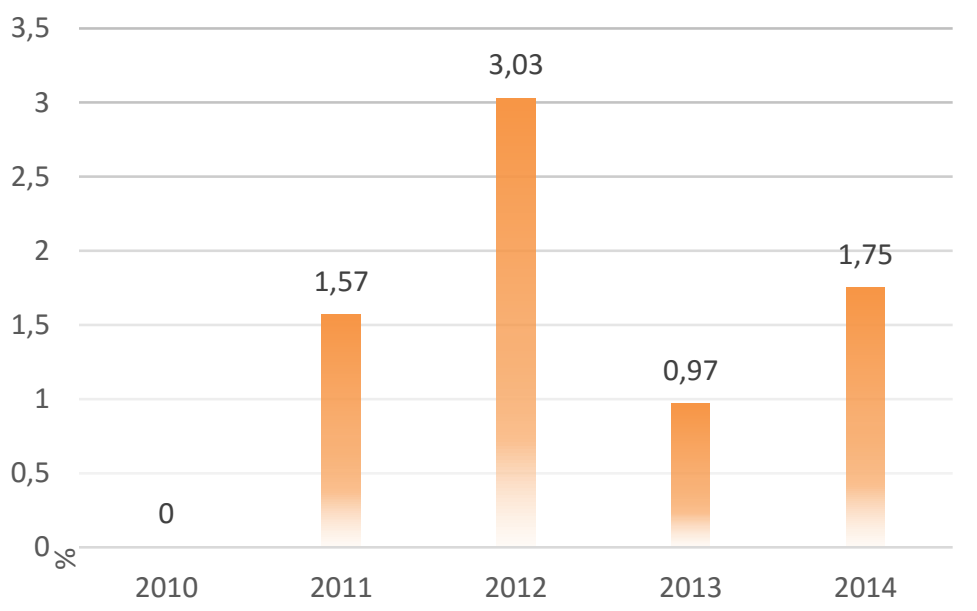

Grafik Hasil kontribusi Laba PD.PASAR tahun 2010 - 2014. Dari peritungan tabel di atas dapat diketahui :

a. Pada tahun 2010 didapat kriteria relatif tidak berkontribusi Senilai 0\% dengan laba Senilai 1.423.787.157,88

b. Pada tahun 2011 didapat kriteria kurang berkontribusi senilai 1,57\% dengan laba senilai 207.699.303,00 dibagi dengan total laba penyertaan modal pada PAD senilai 13.248.936.779,00.

c. Pada tahun 2012 didapat kontribusi senilai 3,03 \% dengan laba senilai 487.308.807,00 dibagi dengan total laba penyertaan modal pada PAD senilai 16.040.602.352,00.

d. Mengalami penurunan di tahun 2013 dengan kriteria relative tidak berkontribusi senilai 0,97\% dengan laba senilai 149.591.500,00 dibagi dengan total laba penyertaan modal pada PAD senilai 15.389.749.772,00.

e. Terjadi peningkatan kembali yang besar ditahun 2014 dengan kriteria kurang berkontribusi senilai 1,75\% dengan laba senilai 283.193.096,00 dibagi dengan total laba penyertaan modal pada PAD senilai 16.091.497.784,00. 
PD. Aneka Usaha Lamongan Jaya

Tabel 4. Hasil kontribusi Laba PD. ANEKA USAHA Tahun 2010 - 2014

\begin{tabular}{ccccc}
\hline Tahun & $\begin{array}{c}\text { Laba } \\
\mathbf{( 2 )}\end{array}$ & $\begin{array}{c}\text { Total Laba Penyertaan } \\
\text { Modal BUMD } \\
\mathbf{( 3 )}\end{array}$ & $\begin{array}{c}\text { \% } \\
\mathbf{( 2 / 3 )}\end{array}$ & kriteria \\
\hline $\mathbf{2 0 1 0}$ & $155.000 .000,00$ & $1.423 .787 .157,88$ & 10,89 & $\begin{array}{c}\text { Mempunyai } \\
\text { kontribusi }\end{array}$ \\
\hline $\mathbf{2 0 1 1}$ & $155.000 .000,00$ & $13.248 .936 .779,00$ & 1,17 & $\begin{array}{c}\text { Kurang } \\
\text { berkontribusi }\end{array}$ \\
\hline $\mathbf{2 0 1 2}$ & $155.000 .000,00$ & $16.040 .602 .352,00$ & 0,96 & $\begin{array}{c}\text { Relatif tidak } \\
\text { berkontribusi }\end{array}$ \\
\hline $\mathbf{2 0 1 3}$ & $180.000 .000,00$ & $15.389 .749 .772,00$ & 1,16 & $\begin{array}{c}\text { Kurang } \\
\text { berkontribusi }\end{array}$ \\
\hline $\mathbf{2 0 1 4}$ & $180.000 .000,00$ & $16.091 .497 .784,00$ & 1,12 & $\begin{array}{c}\text { Kurang } \\
\text { berkontribusi }\end{array}$ \\
\hline
\end{tabular}

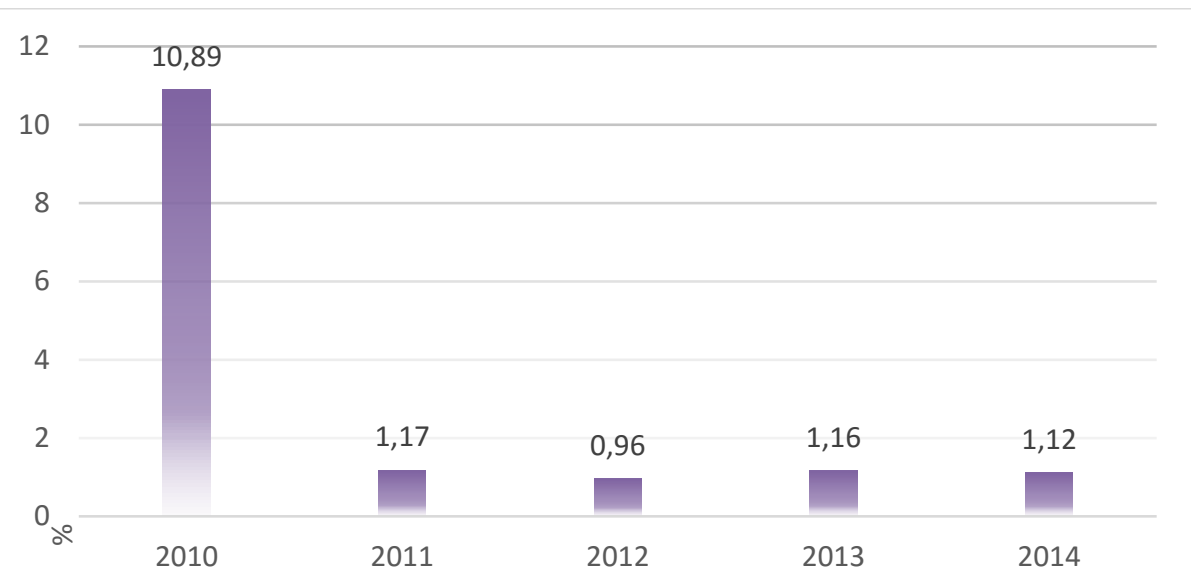

Grafik kontribusi Laba PD. ANEKA USAHA Tahun 2010 - 2014. Dari peritungan tabel diatas dapat diketahui :

a. Pada tahun 2010 didapat didapat kriteria mempunyai kontribusi senilai 10,89 $\%$ dengan laba senilai 155.000.000,00 dibagi dengan total laba penyertaan modal pada PAD senilai 1.423.787.157,88

b. Pada tahun 2011 didapat kriteria kurang berkontribusi senilai 1,17\% dengan laba senilai 155.000.000,00 dibagi dengan total laba penyertaan modal pada PAD senilai 13.248.936.779,00

c. Pada tahun 2012 didapat kriteria relatif tidak berkontribusi senilai $0,96 \%$ dengan laba senilai 155.000.000,00 dibagi dengan total laba penyertaan modal pada PAD senilai 16.040.602.352,00

d. Menglami peningkatan di tahun 2013 dengan kriteria kurang berkontribusi senilai 1,16\% dengan laba senilai 180.000.000,00 dibagi dengan total laba penyertaan modal pada PAD senilai 15.389.749.772,00

e. Terjadi kenaikan yang cukup signifikan ditahun 2014, tetapi masih dengan kriteria kurang kontribusi senilai 1,16\% dengan laba senilai 180.000.000,00 dibagi dengan total laba penyertaan modal pada PAD senilai 16.091.497.784,00

Berdasarkan data di atas dapat disimpulkan bahwa dari keempat Perusahaan daerah kab. Lamongan dari tahun 2010 - 2014 memiliki tingkat kriteria yang berbeda-beda, dan kenaikan serta penurunan yang cukup signifikan. 
Untuk mengetahui keseluruhan total Laba BUMD maka dapat diperoleh dengan perhitungan sebagai berikut.

Tabel 5. Hasil Kontribusi Laba BUMD tahun 2010 - 2014

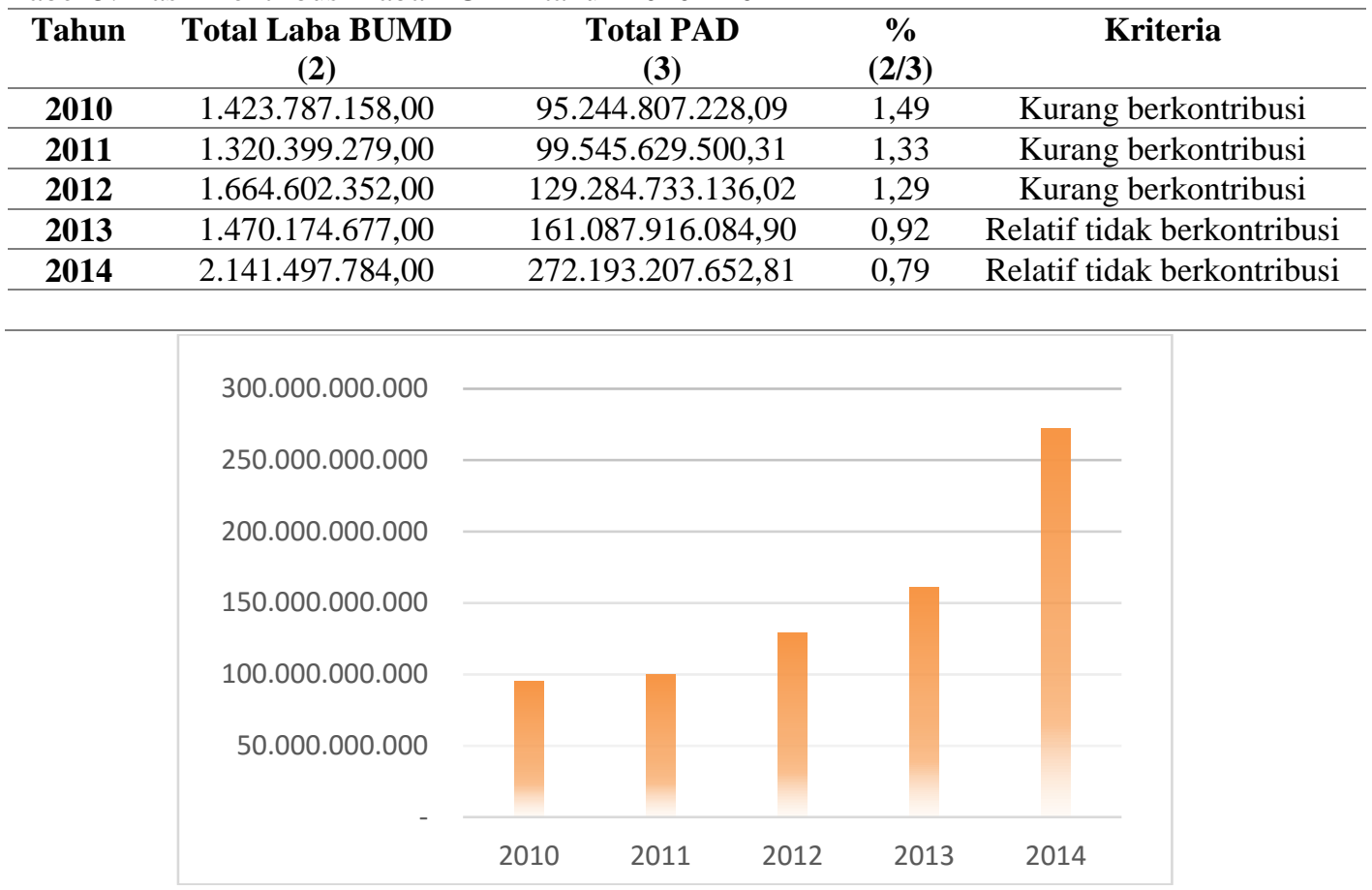

Grafik PAD kabupaten Lamongan 2010-2014

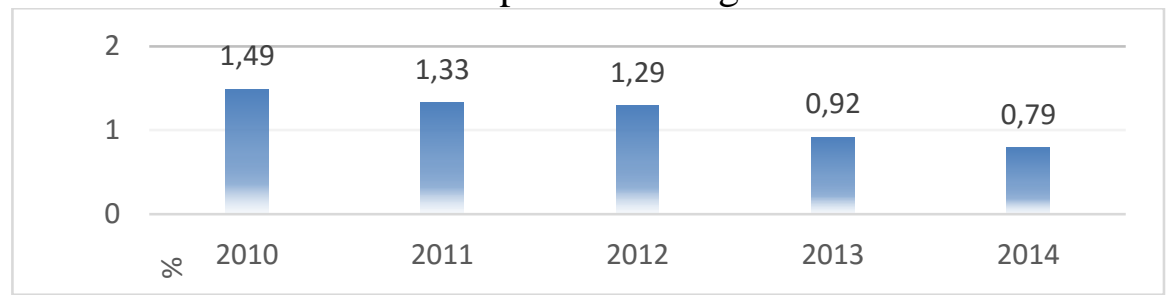

Grafik Kontribusi Laba BUMD tahun 2010-2014

Perhitungan kontribusi pada tabel diats diperoleh dari:

1. Tahun 2010

$$
=(1.423 .787 .158,00 / 95.244 .807 .228,09) \times 100 \%=1,49 \%
$$

2. Tahun 2011

$$
=(1.320 .399 .279,00 / 99.545 .629 .500,31) \times 100 \%=1,33 \%
$$

3. Tahun 2012

$$
=(1.664 .602 .352,00 / 129.284 .733 .136,02) \times 100 \%=1,29 \%
$$

4. Tahun 2013

$$
=(1.470 .174 .677,00 / 161.087 .916 .084,90) \times 100 \%=0,92 \%
$$

5. Tahun 2014

$$
=(2.141 .497 .784,00 / 272.193 .207 .652,81) \times 100 \%=0,79 \%
$$

Berdasarkan tabel di atas dapat diuraikan bahwa Laba BUMD pada tahun 2010 menyumbang kontribusi Rp. 1.423.787.158,00 yang apabila dibandingkan dengan Total Pendapatan Asli Daerah (PAD) sebesar 1,49 \%, karena pendapatan 
dari sektor PAD pada tahun 2010 sejumlah Rp. 95.244.807.228,09. Berarti tahun 2010 Penyertaan Modal Daerah dikatakan kurang berkontribusi.

Pada tahun 2011 mengalami penurunan laba menjadi Rp. 1.320.399.279,00. meskipun mengalami penurunan laba dari tahun sebelumnya, Penyertaan Modal BUMD memiliki penurunan kontribusi pula sebesar 1,33\% dari sektor PAD yang mengalami peningkatan sebesar Rp. 99.545.629.500,31. Dalam hal ini di tahun 2013 Penyertaan Modal BUMD dikatakan kurang berkontribusi.

Pada tahun 2012 mengalami peningkatan laba menjadi Rp. 1.664.602.352,00. meskipun mengalami peningkatan laba dari tahun sebelumnya, Penyertaan Modal BUMD memiliki penurunan kontribusi sebesar 1,29\% dari sektor PAD yang mengalami peningkatan sebesar Rp. 129.284.733.136,02. Dalam hal ini di tahun 2013 Penyertaan Modal BUMD dikatakan kurang berkontribusi.

Pada tahun 2013 mengalami penurunan laba menjadi Rp. 1.470.174.677,00. meskipun mengalami penurunan laba dari tahun sebelumnya, Penyertaan Modal BUMD memiliki penurunan kontribusi pula sebesar 0,92\% dari sektor PAD yang mengalami peningkatan sebesar Rp. 161.087.916.084,90. Dalam hal ini di tahun 2013 Penyertaan Modal BUMD dikatakan Relatif tidak berkontribusi.

Peningkatan laba kembali terjadi di tahun 2014 yakni sebesar Rp. 2.141.497.784,00, tetapi mengalami penurunan kontribusi sebesar 0,79\% dari tahun sebelumnya. Hal itu dikarenakan Pendapatan Asli Daerah (PAD) yang semakin meningkat sebesar Rp. 272.193.207.652,81. Berarti ditahun 2014 penyertaan modal BUMD dikatakan Relatif tidak berkontribusi.

\section{KESIMPULAN}

Dari hasil penelitian dan hasil analisis data dapat diambil kesimpulan sebagai berikut Berdasarkan Hasil analisis perhitungan kontribusi bahwa Laba BUMD pada tahun 2010 sampai tahun tahun 2014 masih memiliki kotribusi meskipun tidak maksimal. Artinya bahwa Laba BUMD masih berkontribusi terhadap Pendapatan Asli Daerah Kabupaten Lamongan meskipun tidak sepenuhnya.

Berdasarkan hasil penelitian dan mencermati upaya optimalisasi Laba Perusahaan Daerah Kabupaten Lamongan yang telah di paparkan, maka peneliti memberikan saran antara lain perbaikan kerja BUMD agar lebih profesional dalam menjalankan tugasnya untuk meningkatkan Pendapatan Asli Daerah (PAD), membentuk lembaga pasar modal untuk menyediakan dana yang murah dan mudah diperoleh Pemerintah Daerah selain itu diperlukan evaluasi secara periodik.

\section{DAFTAR RUJUKAN}

Elita, Dewi. 2002. Identifikasi Sumber-sumber PAD dalam Rangka Pelaksanaan. Otonomi Daerah, Digilib USU

Halim Abdul, Kusufi S.M, 2013, Akuntansi Sektor Publik: Akuntansi Keuangan Daerah, Jakarta: Salemba Empat.

Karmaji, Oyong R, Nurbaya S dan Marth S, 2010, Reinvensi Pembangunan Ekonomi Daerah, Jakarta: Esensi Erlangga Group.

Keputusan Menteri Dalam Negeri dan Otonomi Daerah Nomor 43 Tahun 2000 
Mardiasmo, 2002. Otonomi dan Manajemen Keuangan Daerah, Yogyakarta: PT. Andi.

Nurcholis, Hanif, 2007. Teori dan Praktik Pemerintahan dan Otonomi Daerah. Jakarta : Grasindo.

Perda No.5 tahun 2008 tentang PDAM Kab.Lamongan Perimbangan keuangan antara pemerintah pusat dan daerah

Susanto A.B, Ghifari A.B, Susanto A, Suradinata E, Wijanarko H, Supranto J, Karmaji, Oyong R, Nurbaya S dan Martha S, 2010, Reinvensi pembangunan ekonomi daerah, Esensi Erlangga Group, Jakarta

Tangkilisan, dan Hessel N.S. 2005, Manajemen Publik, Jakarta : PT. Grassindo

Undang-Undang Republik Indonesia Nomor 28 Tahun 2009 Tentang Pajak Daerah dan Retribusi Daerah

UU No. 32 Tahun 2004 Tentang Pemerintahan Daerah

Undang-undang No.33 Tahun 2004 tentang Perimbangan keuangan antara pemerintah pusat dan daerah

Undang-undang RI No. 28 tahun 2009 tentang Pajak daerah dan pendapatan daerah

Undang-Undang Republik Indonesia Nomor 5 Tahun 1962 Tentang Perusahaan Daerah

Undang-Undang RI Nomor 17 Tahun 2003 tentang Keuangan Negara yang dimaksud dengan Perusahaan Daerah 